\title{
Gastric acid secretory response in Helicobacter pylori-positive patients with duodenal ulcer disease
}

\begin{abstract}
Kevan Jacobson MBBCh FRCPC, Naoki Chiba MD FRCPC, Ying Chen BSc, Miguel Barrientos PhD, Cindy James RN, Robert H Riddell MD FRCPath FRCPC, Richard H Hunt MD FRCP FRCPEd FRCPC FACG
\end{abstract}

K Jacobson, N Chiba, Y Chen, M Barrientos, C James, RH Riddell, RH Hunt. Gastric acid secretory response in Helicobacter pylori-positive patients with duodenal ulcer disease. Can J Gastroenterol 2001;15(1):29-39.

BACKGROUND: Patients with duodenal ulcer (DU) have an increased parietal cell mass and sensitivity to secretagogues, with increased acid output.

AIM: To determine the effect of Helicobacter pylori eradication on parietal cell sensitivity and gastric acid secretion.

SUBJECTS AND METHODS: Twenty-five H pylori-positive DU patients and $18 \mathrm{H}$ pylori-negative healthy volunteers were studied. Serum H pylori immunoglobulin G, basal acid output and acid secretory response to graded doses of pentagastrin were determined before and after treatment, at six months and at one year. Subjects were randomly assigned to ranitidine or sucralfate treatment for six weeks, and all DU patients received bismuth subsalicylate, metronidazole and tetracycline for the first two weeks.

RESULTS: $H$ pylori was eradicated in $66 \%$ of patients receiving sucralfate and $92 \%$ receiving ranitidine. Compared with healthy volunteers, DU patients demonstrated a 2.7-fold greater basal acid output, a 1.3-fold greater peak acid output, significantly higher acid output for each dose of pentagastrin and a 1.38-fold increase in the area under the pentagastrin dose acid response curve. Cure of $\mathrm{H}$ pylori, irrespective of ulcer healing regimen, resulted in a gradual decrease in acid secretory capacity with basal acid output, peak acid output and area under the pentagastrin dose acid response curve returning to healthy volunteer levels by one year. No demonstrable differences were observed in parietal cell sensitivity in all subjects before or after treatment. These data suggest that disturbances in acid secretion in $H$ pylori-positive DU patients are not due to an increased parietal cell sensitivity to pentagastrin but rather due to an increased parietal cell mass with increased capacity to secrete acid, which gradually resolves following cure.

Key Words: Duodenal ulcer; Gastric acid secretion; Helicobacter pylori

Réaction sécrétoire de l'acide gastrique chez les patients porteurs d'Helicobacter pylori qui souffrent d'un ulcère gastro-duodénal

CONTEXTE : Les patients souffrant d'un ulcère gastro-duodénal (UGD) présentent une masse plus importante de cellules pariétales et une sensibilité accrue aux sécrétagogues, accompagnées d'une augmentation de la production acide.

OBJECTIF : Déterminer l'effet de l'éradication d'Helicobacter pylori sur la sensibilité des cellules pariétales et la sécrétion acide gastrique.

SUJETS ET MÉTHODE : Vingt-cinq patients porteurs d'H. pylori souffrant d'un UGD et 18 sujets volontaires, exempts d'H. pylori, en bonne santé, ont participé à l'étude. On a mesuré le taux d'immunoglobulines $\mathrm{G}$ sériques contre $H$. pylori, la sécrétion acide basale et la réaction de la sécrétion acide à des doses graduelles de pentagrastine avant et après le traitement, après six mois et au bout d'un an. Les sujets ont été dirigés au hasard vers le traitement à la ranitidine ou au sulfacrate d'une durée de six semaines, et tous les patients atteints d'un UGD ont reçu du subsalicylate de bismuth, du métronidazole et de la tétracycline pendant les deux premières semaines.

RÉSULTATS : H. pylori a été éradiqué chez $66 \%$ des patients traités au sulfacrate et chez $92 \%$ des patients traités à la ranitidine. Comparativement aux sujets volontaires en santé, les patients souffrant d'un UGD présentaient

voir page suivante

Division of Gastroenterology, Department of Medicine, McMaster University Medical Centre, Hamilton, Ontario

Correspondence: Dr Richard H Hunt, Division of Gastroenterology, Room 4W8, Hamilton Health Sciences Corporation, McMaster Division,

1200 Main Street West, Hamilton, Ontario L8N 325. Telephone 905-521-2100 ext 76404, fax 905-521-5072, e-mail huntr@mcmaster.ca

Received for publication January 4, 2000. Accepted September 7, 2000 
une sécrétion acide basale 2,7 fois plus importante, un pic d'acidité 1,3 fois plus élevé, une production de secrétions acides significativement plus forte pour chaque dose de pentagastrine et une surface sous la courbe de la réaction acide à la dose de pentagastrine 1,38 fois plus grande. L'élimination d'H. pylori, peu importe le traitement curatif de l'ulcère, s'est traduite par une diminution progressive de la capacité sécrétoire acide; ainsi, la sécrétion acide basale, le pic d'acidité et la surface sous la courbe de la réaction acide à la dose de pentagastrine ont rejoint les valeurs des sujets sains au bout d'un an. Aucune différence démontrable n'a été observée dans la sensibilité des cellules pariétales chez tous les sujets avant et après le traitement. Les résultats donnent à penser que les troubles de la sécrétion acide chez les patients porteurs d'H. pylori qui souffrent d'un UGD ne sont pas dus à une sensibilité accrue des cellules pariétales à la pentagastrine mais plutôt à une augmentation de la masse de cellules pariétales, qui entraîne une sécrétion accrue acide, mais celle-ci se résorbe graduellement après la guérison.
$\mathrm{T}$ he relationship between Helicobacter pylori infection and duodenal ulcer (DU) disease is well established. $H$ pylori infection is documented in up to $95 \%$ of patients with DU and is associated with an increase in gastric acid secretion. Although acid suppression results in healing of DU, eradication of infection is required to prevent ulcer recurrence (1-5). The exact mechanisms by which $H$ pylori predisposes patients to DU remain to be determined.

It has long been recognized that patients with DU have an increased parietal cell mass, resulting in an increased maximal acid-secretory capacity $(6,7)$. Parietal cell hyperplasia is seen after treatment with gastrin (8) as well as pentagastrin (9), suggesting that the hypergastrinemia associated with $H$ pylori infection (10-13) is responsible for the increased parietal cell mass in patients with DU. Furthermore, some studies have demonstrated that DU patients have an increased parietal cell sensitivity to secretagogues (14-16). Thus, the increased capacity and responsiveness of the parietal cells to secrete acid (17), together with the impaired inhibitory control mechanisms on acid secretion, including a reduced somatostatin concentration in the gastric mucosa $(18,19)$, lead to acid hypersecretion in patients with DU.

Several studies have suggested that the acid secretory responses following ulcer healing vary according to the therapeutic agent used. These studies have demonstrated that the acid secretory response and parietal cell sensitivity decrease with DU healing following treatment with sucralfate but remain essentially unchanged following ulcer treatment with ranitidine (20-23). The observed failure of ranitidine to decrease the secretory responses has been attributed to altered receptor regulation and/or acid rebound, which has been documented both in healthy volunteers and in subjects with healed DU following treatment with $\mathrm{H}_{2}$-receptor antagonists (24-27). Whether this effect is simply due to an increase in parietal cell mass, to an increase in $\mathrm{H}_{2}$-receptor sensitivity or to a true biological $\mathrm{H}_{2}$ - receptor upregulation is unclear.

In the present study, we aimed to determine whether cure of $H$ pylori infection leads to a decrease in parietal cell mass and sensitivity to pentagastrin, and examine the influence of different ulcer treatments. $H$ pylori infection was treated with bismuth-based triple therapy plus either sucralfate or ranitidine, which was standard therapy at the time of commencement of the study. Parietal cell mass was measured by peak acid output (PAO), and parietal cell sensitivity measured by the median effective dose $\left(\mathrm{ED}_{50}\right)$ in response to pentagastrin.

\section{PATIENTS AND METHODS}

Subjects studied: Twenty-seven patients -26 male and one female - with uncomplicated DU disease were recruited at McMaster University Medical Centre, Hamilton, Ontario, between 1991 and 1995. For each patient, a DU was documented endoscopically within one year of commencement of the study. Ten patients were smokers. $H$ pylori status was confirmed by serology, histology and culture of antral and body biopsies. Twelve patients had an active DU, and one patient also had a prepyloric ulcer at the start of the study. None of the patients were taking an $\mathrm{H}_{2}$-receptor antagonist, omeprazole, bismuth compound or antibiotics within four weeks of commencement of the study. In addition, none of the patients were on nonsteroidal anti-inflammatory drugs; however, one patient with polycythemia rubra vera who was on acetylsalicylic acid at the time of inclusion was maintained on acetylsalicylic acid (Table 1). Eighteen H pylorinegative healthy male volunteers with no prior history of peptic ulcer disease were recruited through local advertisements within the catchment area of the hospital and were also studied. None of the volunteers were taking any medication at the time of study. $\mathrm{H}$ pylori status was determined in the same manner as with the DU patients. Individuals with a known allergy to study drugs or related products were excluded. Other exclusion criteria included any contraindication to oral or nasal intubation required for endoscopy or secretory tests.

This study was designed in accordance with the declaration of Helsinki/Tokyo and approved by the Research Advisory Committee of the McMaster University Medical Centre. Written informed consent was obtained from all participants before commencement of the study.

Study design: Before inclusion in the study, patients and volunteers underwent screening by medical history, physical examination and routine blood work including $H$ pylori serology and urinalysis. All subjects underwent upper gastrointestinal endoscopy followed by acid secretory studies.

Investigations were repeated in study subjects at six weeks, and only in the $H$ pylori-positive patients at six months and 12 months after commencement of the study. Patients who failed initial cure were retreated, then restudied six weeks later, and at six months and one year after cure. Endoscopy and biopsy: At endoscopy, four biopsies were taken from the antrum $(5 \mathrm{~cm}$ from the pylorus on the greater curve) and two from the body $(5 \mathrm{~cm}$ from the gastroesophageal junction on the greater curve) for histological examina- 
TABLE 1

Post-treatment Helicobacter pylori status and follow-up of the study population

\begin{tabular}{|c|c|c|c|c|c|c|}
\hline \multirow{2}{*}{$\frac{\text { Status }}{\text { H pylori cure }}$} & \multicolumn{2}{|c|}{$\begin{array}{c}\text { Post-treatment }(n=25) * \\
\text { (acid secretory studies, } n=23 \text { ) }\end{array}$} & \multicolumn{2}{|c|}{ Six months after treatment $(n=15)^{\dagger}$} & \multicolumn{2}{|c|}{ One year after treatment $(n=12)$} \\
\hline & $20(80 \%)$ & 8 Sucralfate $(66 \%)$ & 13 & 6 Sucralfate & 11 & 6 Sucralfate \\
\hline \multirow[t]{2}{*}{ Failed initial cure } & $5(20 \%)$ & 4 Sucralfate (34\%) & 2 & 1 Sucralfate & 1 & 1 Sucralfate \\
\hline & & 1 Ranitidine (8\%) & & 1 Ranitidine & & - \\
\hline
\end{tabular}

*After treatment, 6/52 after commencement of study (4/52 after triple therapy). Two patients refused post-treatment acid secretory studies but underwent other investigations. One ranitidine patient was confirmed $\mathrm{H}$ pylori-negative after treatment but dropped out. One sucralfate patient failed eradication and was retreated (see below). Nineteen who were cured and four who failed to be cured had post-treatment acid secretory studies. One sucralfate patient was $\mathrm{H}$ pylori-negative on histology and culture but had two ulcers in the duodenal cap and was retreated with omeprazole $40 \mathrm{mg}$ bid and amoxicillin $750 \mathrm{mg}$ tid for two weeks with healing (followed for the total duration of the study, and because acid secretory responses were no different from those of patients with healed ulcers, was incorporated in the initial cured analysis). Patients who failed initial cure were retreated with two weeks of omeprazole 20 mg bid plus amoxicillin $750 \mathrm{mg}$ tid ( $n=3$; cure was confirmed by biopsy in one patient taking sucralfate and one taking ranitidine; one patient taking sucralfate who refused further treatment and follow-up failed to be cured), or erythromycin $250 \mathrm{mg}$ qid if allergic to penicillin ( $n=1$; one sucralfate patient was still $\mathrm{H}$ pyloripositive on ${ }^{14}$ carbon urea breath test after retreatment and refused further treatment and follow-up). One sucralfate patient was not retreated because vagotomy and pyloroplasty were required; the patient was $\mathrm{H}$ pylori-negative on histology and culture after surgery, and acid secretory studies were done before but not after surgery. ${ }^{+}$Six months after treatment, of the cured patients, five refused follow-up (one sucralfate patient and one ranitidine patient) and two were lost to follow-up (one sucralfate patient and on ranitidine patient). For retreated patients, see patients who failed initial cure. ${ }^{\ddagger}$ One year after treatment, one ranitidine patient was withdrawn following hematemesis secondary to acetylsalicylic acid gastropathy requiring misoprostol and one ranitidine patient was lost to follow-up. One ranitidine patient was retreated, and the cured patient refused follow-up

tion and culture. Biopsies for histology were placed in neutral buffered formalin, and stained with hematoxylin and eosin; the inflammation was graded as mild, moderate or severe. The presence of $H$ pylori was confirmed with the Warthin-Starry stain. The specimens for culture were placed in a sterile container, plated on blood-chocolate agar and Skirrow's medium, and incubated under microaerophilic conditions at $35^{\circ} \mathrm{C}$.

Acid secretory study: Within $72 \mathrm{~h}$ of each endoscopy, an acid secretory study was performed using stepped doses of pentagastrin (12). Following a $12 \mathrm{~h}$ overnight fast, a Salem Sump nasogastric tube (Sherwood Medical, Ireland) (14 FG) was passed into the stomach via the nose to a distance of $55 \mathrm{~cm}$ and the position checked using the water recovery test (28). Gastric juice was collected in $10 \mathrm{~min}$ aliquots by continuous aspiration using a Harvard aspiration pump assisted by manual aspiration. Residual juice was collected for the first $30 \mathrm{~min}$ and then basal secretion collected for the next $30 \mathrm{~min}$. Pentagastrin (Peptavlon, Wyeth-Ayerst Canada Inc, Canada) was infused intravenously in graded doses of $0.0028,0.0083,0.025,0.075,0.222,0.667,2.0$ and $6.0 \mu \mathrm{g} / \mathrm{kg} / \mathrm{h}$. Each dose of pentagastrin was made up to a volume of $50 \mathrm{~mL}$ with $0.9 \%$ sodium chloride and infused into a forearm vein by a syringe infusion pump for $30 \mathrm{~min}$. During each dose infusion, gastric juice was collected in $10 \mathrm{~min}$ aliquots over the $30 \mathrm{~min}$ period. The volume of each $10 \mathrm{~min}$ gastric juice collection was recorded, and the hydrogen ion activity measured by titration with $0.1 \mathrm{~mol} / \mathrm{L}$ sodium hydroxide to $\mathrm{pH} 7.0$ using an autotitrator (Radiometer ETS 822, Denmark). The acid output for each $10 \mathrm{~min}$ period was calculated as the product of volume and hydrogen ion activity, and the acid output for each step dose of pentagastrin was determined by the sum of the three consecutive 10 min periods for that dose, expressed in mmol.
Acid secretory response: Basal acid output (BAO) was determined by taking the gastric juice collected over the second $30 \mathrm{~min}$ basal period and expressed as $\mathrm{mmol} / 30 \mathrm{~min}$. PAO was determined by taking the highest acid output over a $30 \mathrm{~min}$ period in response to one dose of pentagastrin and expressed as $\mathrm{mmol} / 30 \mathrm{~min}$. The pentagastrin dose-response data for each patient were analyzed and the area under the curve $\left(\mathrm{AUC}_{\mathrm{p}}\right)$ calculated and expressed as mmol. In addition, the apparent parietal cell sensitivity $\left(D_{50}\right)$ and intrinsic parietal cell sensitivity $\left(\mathrm{K}_{\mathrm{m}}\right)$ were determined as previously described by Hirschowitz (29), using an exponential model,

$$
\mathrm{V}=\mathrm{V}_{\max }\left(1-\exp ^{\mathrm{c}-\mathrm{bD}}\right)
$$

where $\mathrm{V}=$ output and $\mathrm{D}=$ dose of pentagastrin. From this analysis, we obtained the threshold dose:

$$
\begin{aligned}
\mathrm{T} & =\mathrm{c} / \mathrm{b} \\
\mathrm{K}_{\mathrm{m}} & =\ln 2 / \mathrm{b} \\
\mathrm{D}_{50} & =\mathrm{K}_{\mathrm{m}}-\mathrm{T}
\end{aligned}
$$

$\mathrm{D}_{50}$ is the dose of pentagastrin required to raise the output from basal to $50 \%$ of the calculated maximum output $\left(\mathrm{V}_{\max }\right)$ and is an index of apparent sensitivity. $\mathrm{K}_{\mathrm{m}}$ is a measure of intrinsic sensitivity and is the dose of pentagastrin needed to raise the output to $50 \%$ of $\mathrm{V}_{\max }$, assuming that the basal output was zero.

Serology: Serology was determined using a standard Pylori Stat test kit (ELISA for H pylori immunoglobulin [Ig] $\mathrm{G}$ antibody in human serum; BioWhittaker Inc, USA). With this kit, serum samples were tested concomitantly with three standards and two serum controls. Labelled index values for each standard were provided for linear regression analysis of test results. Control serum samples with predicted index values were used to confirm test validity. The results are expressed as absorbance, and an optical density of 0.80 was 
TABLE 2

Patient characteristics, drug treatment and Helicobacter pylori status after treatment with sucralfate or rinitidine

\begin{tabular}{|c|c|c|c|c|c|c|}
\hline Subjects & $\mathbf{n}$ & Sex & $\begin{array}{c}\text { Age range } \\
\text { (years) }\end{array}$ & $\begin{array}{l}\text { Weight }(\mathbf{k g}) \\
\text { mean } \pm \text { SEM }\end{array}$ & $\mathbf{R x}$ & H pylori eradication* \\
\hline $\begin{array}{l}\text { H pylori-positive patients with } \\
\text { duodenal ulcer }\end{array}$ & $\begin{array}{c}24 \\
1\end{array}$ & $\begin{array}{l}\text { Male }(96 \%) \\
\text { Female (4\%) }\end{array}$ & $19-67$ & $82.71 \pm 4.18$ & $\begin{array}{l}12 \text { Sucralfate (48\%) } \\
13 \text { Ranitidine (52\%) }\end{array}$ & $\begin{array}{c}8(66 \%) \\
12(92 \%)^{*}\end{array}$ \\
\hline Healthy volunteers & 18 & Male $(100 \%)$ & $20-42$ & $79.75 \pm 3.36$ & $\begin{array}{l}8 \text { Sucralfate } \\
10 \text { Ranitidine }\end{array}$ & $\begin{array}{l}- \\
-\end{array}$ \\
\hline
\end{tabular}

${ }^{*} \mathrm{H}$ pylori eradication 6/52 patients after commencement of study (4/52 after triple regimen); ${ }^{\dagger} \mathrm{P}=0.05$ compared with eradication rate achieved with sucralfate

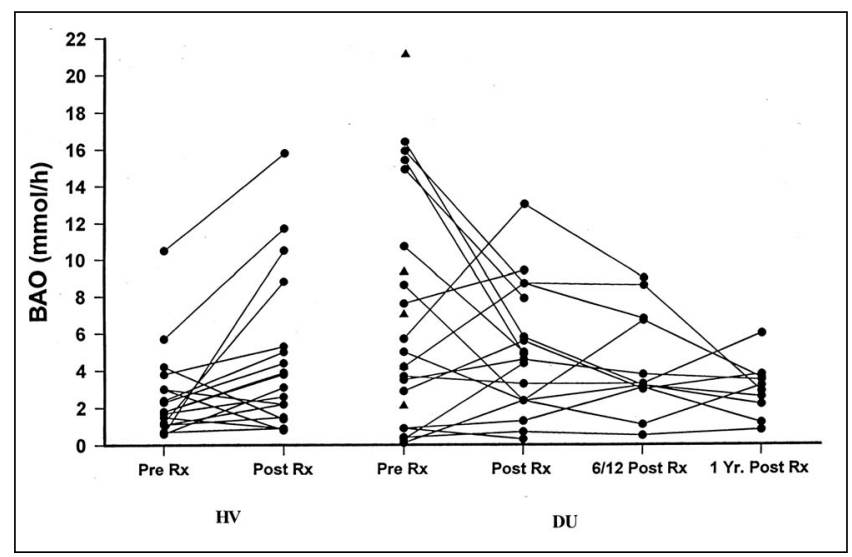

Figure 1) Basal acid output (BAO) in healthy volunteers (HV) before treatment (Pre Rx) and after treatment (Post $R x$ ) and in Helicobacter pylori-positive patients with duodenal ulcer (DU) disease Pre Rx, and one month, six months and one year Post Rx. Compared with $H V$, Pre $R x B A O$ increased in DU patients $(P=0.03)$. In HV Post $R x, B A O$ increased over Pre $R x$ levels $(P=0.02)$, and in DU patients BAO decreased Post Rx but failed to reach significance over Pre Rx levels by one year $(P=0.09)$. H pylori-positive patients cured with one course of eradication therapy; $\mathbf{\Delta} \mathrm{H}$ pylori-positive patients requiring a second course of eradication therapy

defined as seronegative, 0.80 to 0.99 as equivocal and 0.99 as seropositive.

Eradication of $\mathbf{H}$ pylori infection: Following the initial endoscopy and acid secretory study, all subjects were randomly assigned by a computer-generated randomization code to receive a six-week course of either sucralfate $1 \mathrm{~g}$ qid or ranitidine $300 \mathrm{mg}$ per day at bedtime. In addition, the $H$ pyloripositive DU patients also received metronidazole $500 \mathrm{mg}$ tid and tetracycline $500 \mathrm{mg}$ qid for the first week and bismuth subsalicylate one tablet qid for the first two weeks. Compliance was assessed by pill counting at follow-up, and any adverse events were documented in the case study books.

Following the six-week course of therapy, patients who initially failed to cure $H$ pylori were retreated with what was considered to be the most effective therapy at the time (omeprazole and amoxicillin for two weeks).

Statistics: Each patient acted as their own control, and group comparisons were made between patients and healthy volunteers before and after treatment, and with patients before and after treatment, and at six months and one year. Statistical analysis was performed using the Wilcoxon
Signed Rank test for paired data and the Mann-Whitney test for unpaired data. ANOVA was used to compare the doseresponse curves between groups. $\mathrm{P}=0.05$ was considered significant.

\section{RESULTS}

Of the 27 patients recruited to the study, two patients who were randomly assigned to the ranitidine arm of treatment were excluded. One patient was subsequently shown to be $H$ pylori negative before treatment, and the second patient refused any post-treatment investigation because he felt so well. Two additional patients, one in each of the treatment arms, refused acid secretory studies but underwent all other investigations. The patient in the ranitidine arm was $\mathrm{H}$ pylori negative, and the patient in the sucralfate arm was $H$ pylori positive after treatment. The clinical characteristics of the study population are shown in Tables 1 and 2. All healthy volunteers were compliant with their medication, whereas compliance could only be verified in 20 subjects in the patient population. The remaining five individuals failed to return either their pill boxes or compliance cards; however, all otherwise indicated compliance at interview. Three of these patients were $H$ pylori negative after treatment, and two remained $\mathrm{H}$ pylori positive and required a second course of eradication therapy. All patients were included in the analysis.

$H$ pylori eradication was achieved in 20 of $25(80 \%)$ infected patients (Table 2). Of the 13 patients with an active ulcer, healing was demonstrated in all but one patient who required a second course of therapy before confirmed healing. Ranitidine plus triple therapy achieved an eradication rate of $92 \%$, whereas sucralfate plus triple therapy achieved eradication in $66 \%(\mathrm{P}=0.05)$. In general, the medications were well tolerated, with 11 patients complaining of mostly mild, short lived symptoms occurring predominantly during antibiotic use and settling rapidly thereafter. One patient in the sucralfate group required a course of nystatin for oral thrush, and a second patient in the ranitidine group required a two-week course of metronidazole ( $500 \mathrm{mg}$ tid) for diarrhea secondary to Clostridium difficile. Three volunteers complained of mild abdominal discomfort during the first week of therapy. Short term acid secretory response before and after $\mathrm{H}$ pylori eradication: $H$ pylori-positive patients $(n=25$, Table 2$)$ demonstrated a significantly higher mean $\mathrm{BAO}$ than healthy volunteers $(n=18 ; P=0.03$; Figure 1 , Table 3$)$. The 
TABLE 3

Basal and pentagastrin-stimulated acid secretory responses in healthy volunteers $(\mathrm{HV})$ and Helicobacter pylori-positive patients with duodenal ulcer (DU) disease before and after treatment

\begin{tabular}{|c|c|c|c|c|c|c|}
\hline \multirow[b]{2}{*}{ Acid output } & \multicolumn{2}{|c|}{ Before treatment } & \multicolumn{2}{|c|}{ After treatment } & \multirow{2}{*}{$\begin{array}{c}\text { Sixmonths after } \\
\text { treatment } \\
\text { DU (15) }\end{array}$} & \multirow{2}{*}{$\begin{array}{c}\text { One year after } \\
\text { treatment } \\
\text { DU (12) }\end{array}$} \\
\hline & HV (18) & DU (25) & HV (18) & DU (23) & & \\
\hline PAO & $32.1 \pm 1.9$ & $43.4 \pm 2.7^{\pi}$ & $33.7 \pm 2.1$ & $42.0 \pm 2.9^{* *}$ & $36.7 \pm 2.7$ & $31.4 \pm 2.5^{t+}$ \\
\hline$A \cup C_{p}$ & $137.2 \pm 9.3$ & $195.8 \pm 15.9^{\text {fキ }}$ & $145.8 \pm 10.8^{\S \S}$ & $189.9 \pm 14.6^{\text {Iศ }}$ & $173.6 \pm 13.4^{* * *}$ & $145.7 \pm 13.5^{t+t}$ \\
\hline
\end{tabular}

Results are expressed as mean \pm SEM. There were no significant differences for the following comparisons: DU after treatment versus DU before treatment; $D U$ six months after treatment versus DU before treatment; DU one year after treatment versus HV before treatment. ${ }^{*} P=0.03 \mathrm{HV}$ versus DU before treatment; ${ }^{+}$Ranitidine increased the basal acid output/30 $\mathrm{min}(B A O)(P=0.02)$ in HV after treatment versus HV before treatment, whereas sucralfate had no effect; ${ }^{7} P=0.01 \mathrm{DU}$ after treatment versus HV before treatment; ${ }^{\xi} P=0.02 \mathrm{DU}$ six months after treatment versus HV before treatment; $P=0.01 \mathrm{HV}$ versus DU before treatment; ${ }^{* * P}=0.01 \mathrm{DU}$ after treatment versus $\mathrm{HV}$ before treatment; ${ }^{++} P=0.01 \mathrm{DU}$ one year after treatment versus DU before treatment; ${ }^{\neq \neq} P=0.02$ $H V$ versus DU before treatment; ${ }^{S \mathcal{S}}$ Ranitidine increased the area under the pentagastrin dose acid response curve $\left(A U C_{p}\right)(P=0.02)$ in $H V$ after treatment versus HV before treatment, whereas sucralfate had no effect; " $P<0.01 \mathrm{DU}$ after treatment versus HV before treatment; ${ }^{* *} P=0.03 \mathrm{DU}$ six months after treatment versus HV before treatment; ${ }^{+t+} P=0.05 \mathrm{DU}$ one year after treatment versus DU before treatment. PAO Highest acid output/30 mins

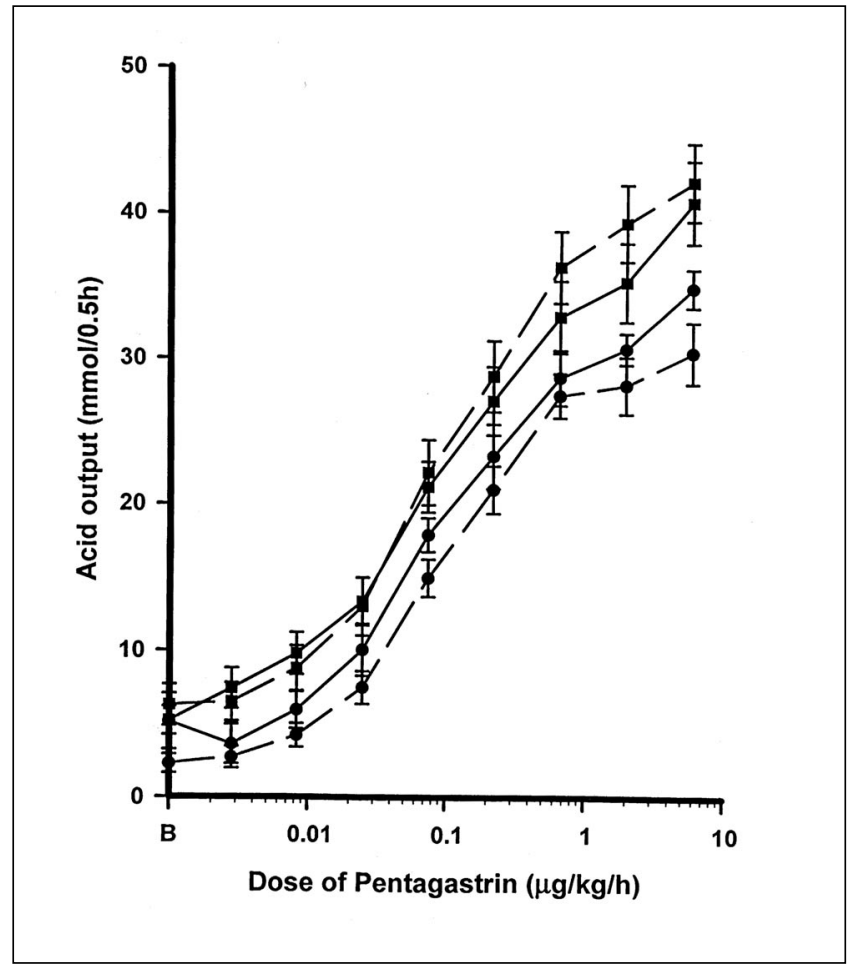

Figure 2) Acid output for graded doses of pentagastrin in 18 healthy volunteers (-) and 23 Helicobacter pylori-positive patients with duodenal ulcer disease $(\mathbf{\Delta})$ before and after treatment. Compared with that in healthy volunteers, acid output increased in duodenal ulcer patients for each graded dose of pentagastrin $(P<0.01)$. Although in duodenal ulcer patients after treatment there was a slight shift in the dose-response curve to the right, the acid output for each graded dose of pentagastrin remained higher than that of healthy volunteers $(P<0.01)$

acid output to each graded dose of pentagastrin was significantly higher than in healthy volunteer levels $(\mathrm{P}<0.01$; Figure 2). Furthermore, $H$ pylori-positive patients showed significantly higher mean $\mathrm{PAO}(\mathrm{P}<0.01$; Figure 3 , Table 3$)$ and $\mathrm{AUC}_{\mathrm{p}}(\mathrm{P}=0.02$; Figure 4, Table 3).

Treatment of all patients $(n=23$; Table 2$)$ was associated with minimal change in BAO (Figure 1, Table 3), PAO (Fig-

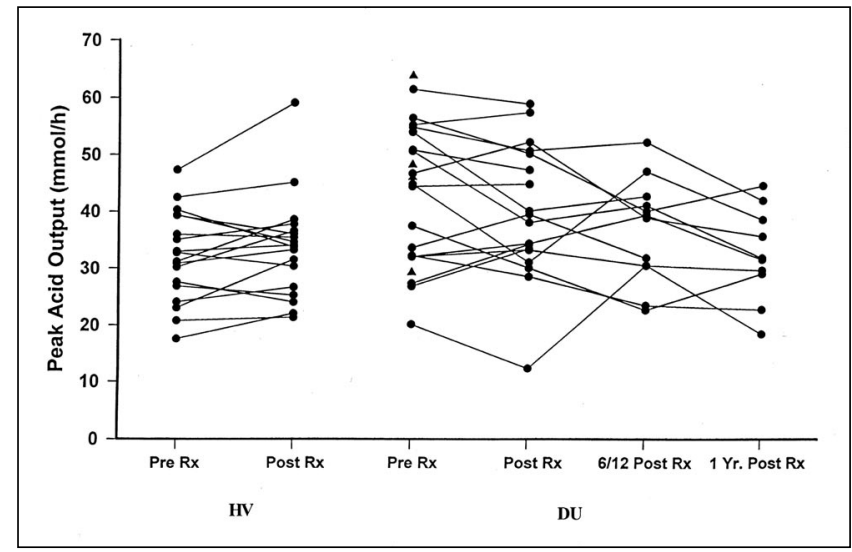

Figure 3) Peak acid output (PAO) in healthy volunteers (HV) before treatment (Pre Rx) and after treatment (Post $R x$ ) and in Helicobacter pylori-positive patients with duodenal ulcer (DU) disease Pre Rx, and one month, six months and one year Post $R x$. Compared with that in $H V$, Pre Rx PAO increased in DU patients $(P<0.01)$. In DU patients, $P A O$ decreased significantly from Pre Rx levels at six months $(P=0.02)$ and one year $(P<0.01)$ Post $R x$. H pylori-positive patients cured with one course of eradication therapy; $\boldsymbol{\Delta} \mathrm{H}$ pylori-positive patients requiring a second course of eradication therapy

ure 3, Table 3), $\mathrm{AUC}_{\mathrm{p}}$ (Figure 4, Table 3) and shift in the dose-response curve (Figure 2). However, when patients were separated into those who were cured by initial therapy $(n=20)$ and those who were not $(n=5)$, differences in pretreatment acid secretory responses were seen (Figure 5, left).

Cure of $H$ pylori infection four weeks after triple therapy $(\mathrm{n}=19$; Tables 1 and 2$)$ was associated with a decrease in $\mathrm{BAO}$ (Figure 1), PAO (Figure 3) and $\mathrm{AUC}_{\mathrm{p}}$ (Figure 4), and a shift in the dose-response curve to the right (Figure 5, right). However, the decrease in these parameters failed to reach significance over pretreatment levels. Moreover, the acid output to each graded dose of pentagastrin remained significantly higher than healthy volunteer post-treatment levels $(\mathrm{P}<0.01 ;$ Figure 5$)$. No significant differences were noted between patients treated with ranitidine and those treated 


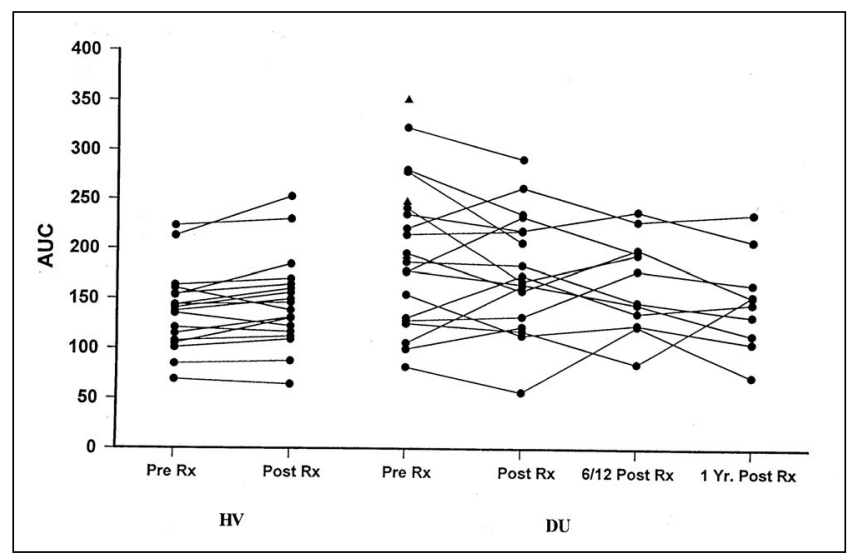

Figure 4) Area under the pentagastrin dose response curve $\left(A U C_{p}\right)$ in healthy volunteers (HV) before treatment (Pre Rx) and after treatment (Post $R x$ ) and in Helicobacter pylori-positive patients with duodenal ulcer (DU) disease Pre Rx, and one month, six months and one year Post Rx. Compared with that in $\mathrm{HV}$, the pretreatment $\mathrm{AUC}_{p}$ increased in DU patients $(P=0.02)$. In HV Post $R x$, the $\mathrm{AUC}_{p}$ increased compared with Pre Rx levels $(P=0.02)$ and in DU patients Post $R x$, the AUC ${ }_{p}$ decreased but just failed to reach significance over Pre Rx levels at one year Post $R x(P=0.06)$. H pylori-positive patients cured with one course of eradication therapy; $\mathbf{\Delta}$ H pylori-positive patients requiring a second course of eradication therapy

with sucralfate, with the exception that patients treated with sucralfate showed a $45 \%$ decrease in BAO $(\mathrm{P}=0.04)$, whereas, with ranitidine treatment, the $\mathrm{BAO}$ remained essentially unchanged.

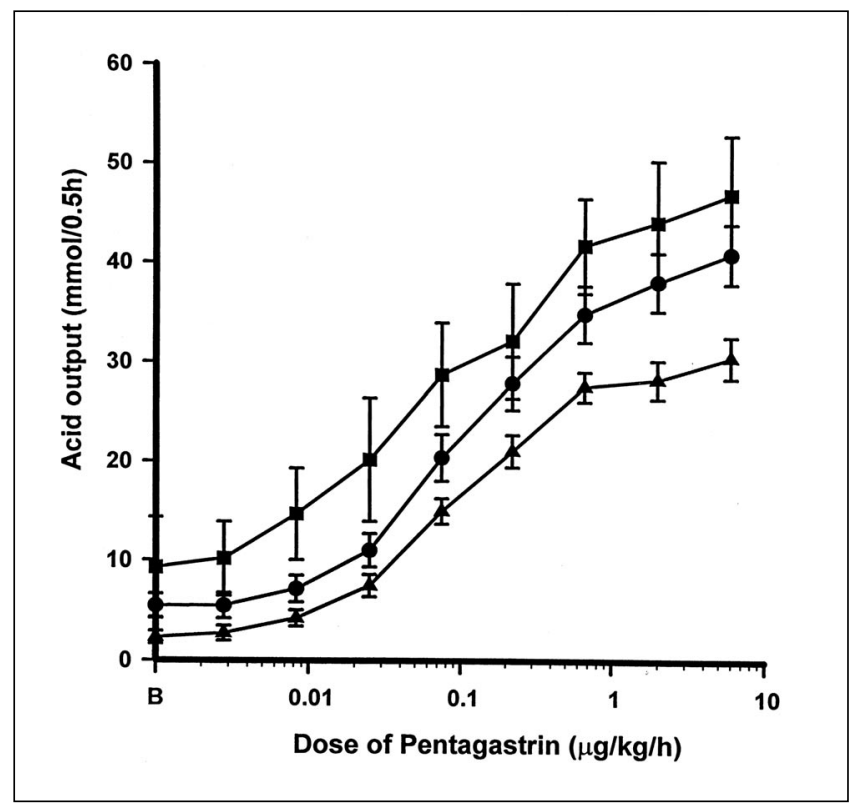

$H$ pylori-positive patients who remained infected $(n=5)$ demonstrated higher pretreatment acid output for the secretory parameters measured than patients who achieved initial cure, and these parameters remained unchanged with treatment ( $\mathrm{n}=4$; Figures 1, 3, 4, 5).

In healthy volunteers, sucralfate treatment had no effect on any of the acid secretory parameters measured, whereas ranitidine treatment resulted in a significant increase in both $\mathrm{BAO}(\mathrm{P}=0.02$; Figure 1, Table 3$)$ and $\mathrm{AUC}_{\mathrm{p}}(\mathrm{P}=0.02$; Figure 4, Table 3$)$.

Serology and histology: In $H$ pylori-positive patients, the mean optical density of the ELISA test was $2.83 \pm 0.19$, representing a sixfold increase over that of healthy volunteers $(0.47 \pm 0.27 ; \mathrm{P}<0.001 ;$ Figure 6$)$. Cure of infection resulted in a $10 \%$ decrease from pretreatment levels $(\mathrm{P}=0.03$; Figure 6$)$. In patients who failed initial cure, pretreatment mean optical density was $3.59 \pm 0.26(\mathrm{P}=0.03$ compared with pretreatment cure), and this value remained unchanged following treatment. Moreover, in $80 \%$ (four of five) of the patients who failed initial cure, a moderate $(n=1)$ to severe $(n=3)$ pretreatment chronic active gastritis was noted, whereas in cured patients only $30 \%$ (six of 20) showed a moderate $(n=4)$ to severe $(n=2)$ pretreatment chronic active gastritis. After treatment, $92 \%$ of patients demonstrated either mild chronic gastritis $(\mathrm{n}=21)$ or no significant abnormality $(n=2)$, whereas two patients who remained infected still demonstrated severe chronic active gastritis.

Long term acid secretory response: All cured patients dem-

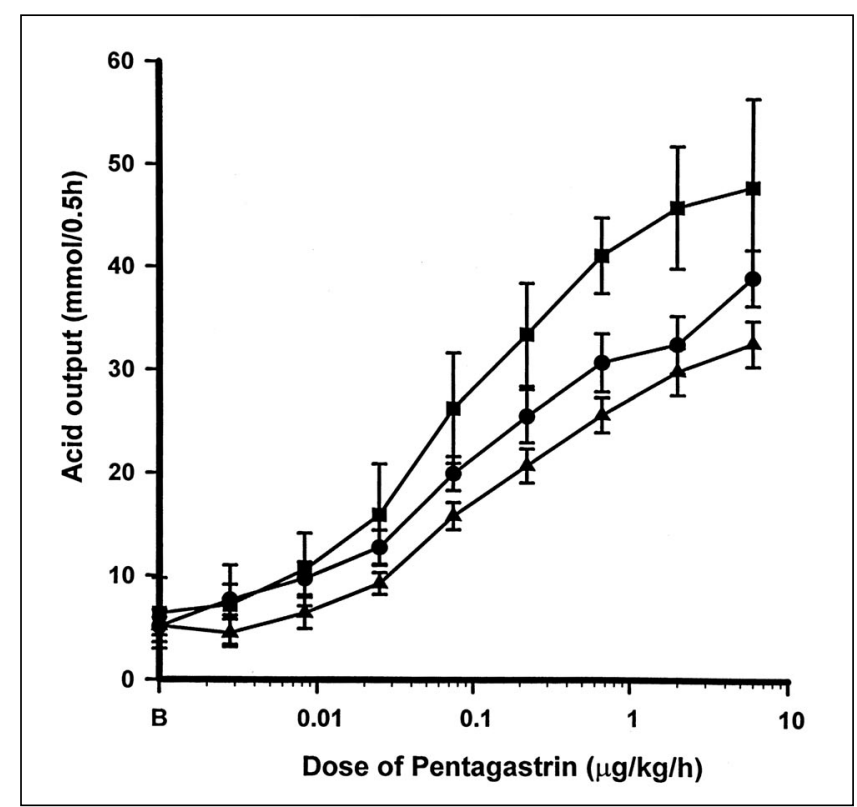

Figure 5) Left Pretreatment acid output to graded doses of pentagastrin in 18 healthy volunteers $(\boldsymbol{\Delta})$ and in 20 Helicobacter pylori-positive patients with duodenal ulcer disease who were cured by initial therapy $(\mathbf{O})$ and in five who were not $(\mathbf{\square})$. Compared with that in healthy volunteers, acid output increased for each graded dose of pentagastrin in patients who achieved initial cure $(P<0.01)$. In patients who failed initial cure, acid output was higher for each dose of pentagastrin than in those who achieved cure $(P<0.01)$. Right Post-treatment acid output to graded doses of pentagastrin in 18 healthy volunteers $(\mathbf{\Delta})$ and in $19 \mathrm{H}$ pylori-positive patients with duodenal ulcer disease who were cured by initial therapy $(\mathbf{O})$ and four who were not $(\mathbf{\square})$. Very little change is seen in the acid output for each graded dose of pentagastrin, with the exception of a slight shift to the right of the dose response curve for the higher doses of pentagastrin in the $\mathrm{H}$ pylori-positive patients who achieved cure. $P<0.01$ healthy volunteers versus patients cured by initial therapy; $P<0.01$ patients cured by initial therapy compared with patients not cured by initial therapy 


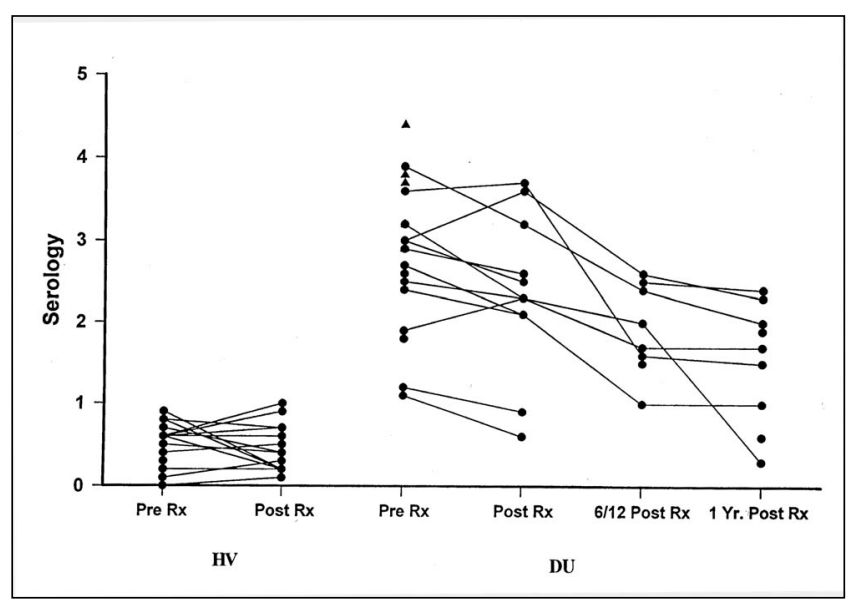

Figure 6) Helicobacter pylori serology titres in healthy volunteers $(H V)$ before treatment (Pre Rx) and after treatment (Post Rx) and in $\mathrm{H}$ pylori-positive patients with duodenal ulcer (DU) disease Pre Rx, and one month, six months and one year Post $R x$. Compared with those in $H V$, Pre Rx serological titres increased in DU patients $(P<0.01)$, and treatment in DU was associated with a decrease from Pre Rx levels $(P=0.03)$. Pre $R x$ serological titres in patients who failed initial cure were higher than those of patients achieving initial cure $(P=0.03)$ and remained unchanged Post Rx. Postcure serological titres continued to decrease compared with Pre Rx levels $(P<0.01$ at six months and one year) but remained higher than those of $\mathrm{HV}(P<0.01)$. $\mathrm{H}$ pylori-positive patients cured with one course of eradication therapy; $\boldsymbol{\Delta} \mathrm{H}$ pyloripositive patients requiring a second course of eradication therapy

onstrated a gradual decrease in $\mathrm{BAO}$ and a shift in the pentagastrin dose-response curve to the right (Figure 7). Six months after cure, all patients $(\mathrm{n}=15)$ demonstrated a slight decrease in basal and pentagastrin-stimulated acid output. However, the BAO (Figure 1, Table 3), PAO (Figure 3, Table 3 ) and $\mathrm{AUC}_{\mathrm{p}}$ (Figure 4, Table 3) failed to reach significance compared with pretreatment levels. Furthermore, the $\mathrm{BAO}$ and $\mathrm{AUC}_{\mathrm{p}}$ remained significantly elevated over pretreatment healthy volunteer levels, whereas the $\mathrm{PAO}$ was no longer significantly different.

By one year after cure, in all patients $(n=12)$, the BAO (Figure 1, Table 3), PAO (Figure 3, Table 3) and $\mathrm{AUC}_{\mathrm{p}}$ (Figure 4, Table 3) returned to pretreatment healthy volunteer levels. The decrease in $\mathrm{BAO}$ just failed to reach significance compared with pretreatment levels $(\mathrm{P}=0.09)$, whereas the PAO and $\mathrm{AUC}_{\mathrm{p}}$ decreased significantly $(\mathrm{P}=0.01$ and $\mathrm{P}=0.05$, respectively). No differences were noted between patients treated with sucralfate and those treated with ranitidine.

Serology and histology: In all cured patients, the H pylori $\operatorname{IgG}$ concentration continued to decrease over time, with an additional $14 \%$ decrease over post-treatment levels at six months, and a further $28 \%$ decrease over the six-month level one year after cure (Figure 6). In response to $H$ pylori cure, the histological appearance continued to improve. Six months after cure, of 16 patients in whom an upper gastrointestinal endoscopy with biopsy was performed, seven demonstrated complete resolution of the inflammatory response and nine showed mild nonspecific chronic gastritis. One year after cure, three additional patients showed resolu-

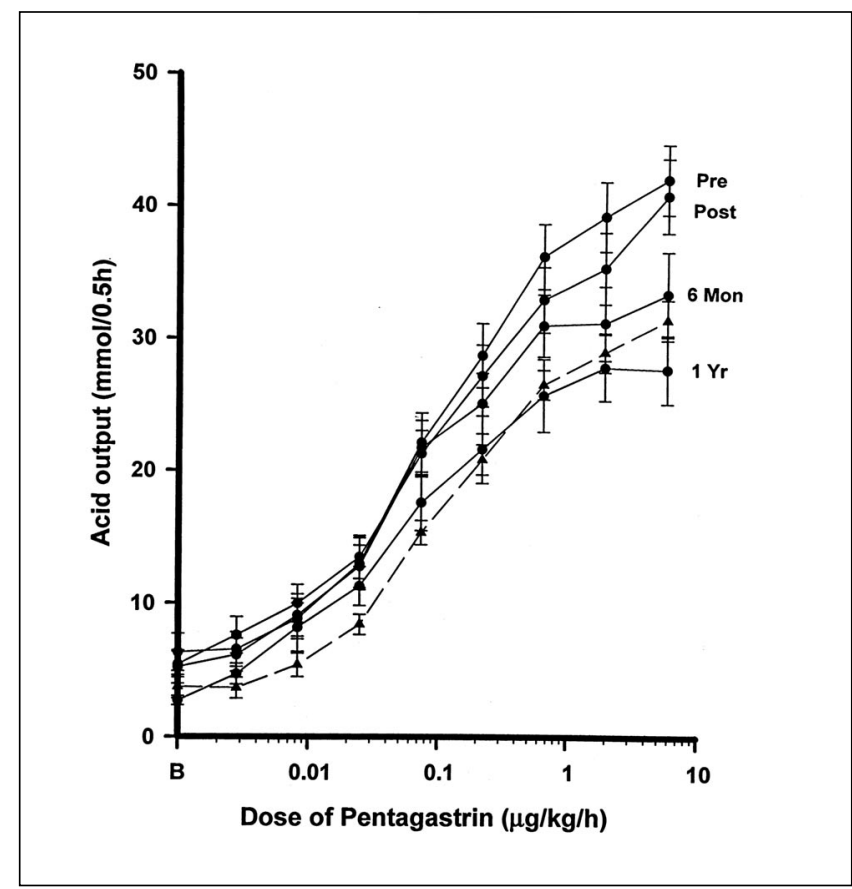

Figure 7) Acid output for graded doses of pentagastrin in healthy volunteers $(\mathbf{\Delta})$ before treatment (Pre Rx) and $\mathrm{H}$ pylori-positive patients with duodenal ulcer disease (-) Pre Rx, and one month after treatment (Post $R x)$ (see Figure 2), six months and one year Post $R x$. Post $R x$, there was a gradual shift in the dose-response curve to the right, with a significant difference noted over the Pre Rx dose-response curve at six months $(P<0.01)$, and the dose-response curve is similar to that of healthy volunteers one year Post $R x$

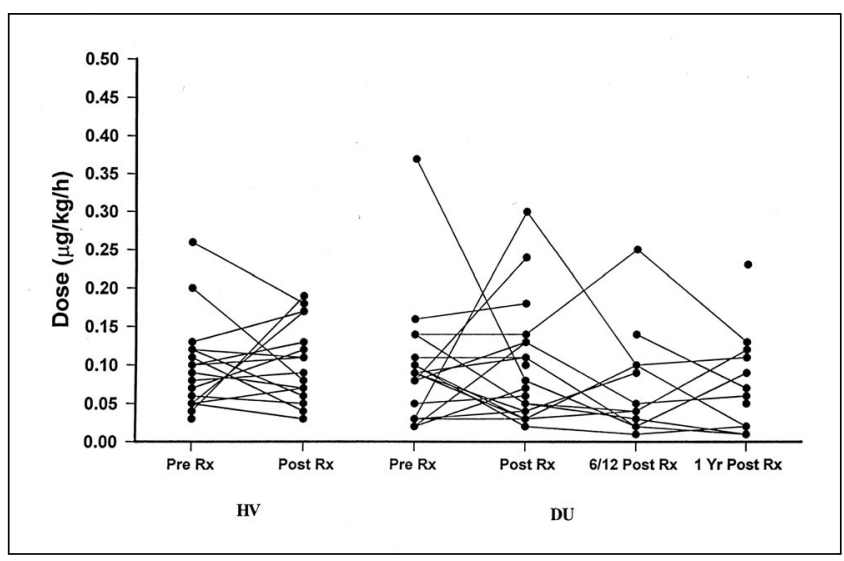

Figure 8) Apparent parietal cell sensitivity (median effective dose) in healthy volunteers (HV) before treatment (Pre Rx) after treatment (Post Rx) and in H pylori-positive patients with duodenal ulcer (DU) disease Pre Rx, and one month, six months and one year Post Rx. No differences are noted in the median effective dose in HV Pre Rx and Post Rx and in DU patients Pre Rx, and one month, six months and one year Post Rx

tion of the inflammatory response and the remaining three patients had mild nonspecific chronic gastritis.

Parietal cell sensitivity: $H$ pylori-positive patients, irrespective of ulcer healing therapy, failed to demonstrate any differences in either apparent $\left(\mathrm{ED}_{50}\right.$; Figure 8$)$ or intrinsic $\left(\mathrm{K}_{\mathrm{m}}\right.$; 


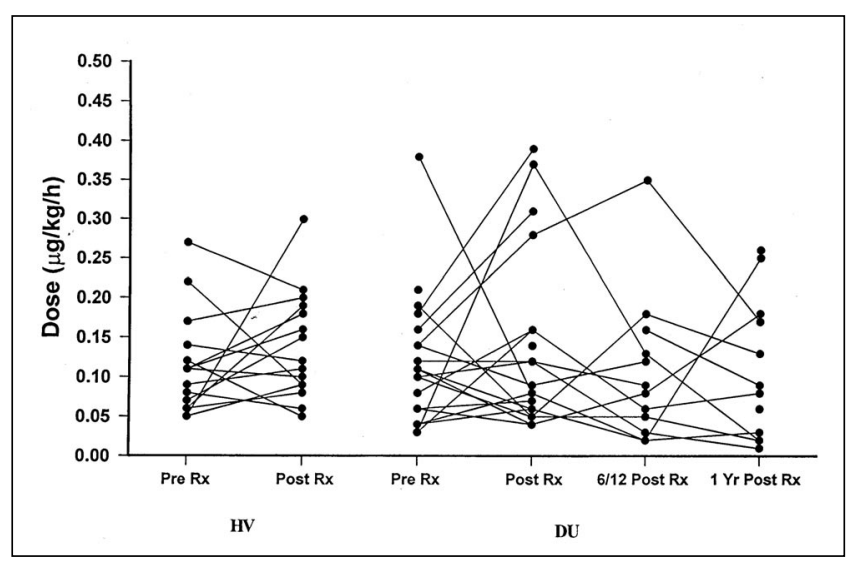

Figure 9) Intrinsic parietal cell sensitivity $\left(K_{m}\right)$ in healthy volunteers (HV) before treatment (Pre Rx) and after treatment (Post Rx), and in $\mathrm{H}$ pylori-positive patients with duodenal ulcer (DU) disease Pre $R x$, and one month, six months and one year Post $R x$. No differences are noted in the $K_{m}$ in HV Pre Rx and Post Rx and in DU patients Pre Rx, and one month, six months and one year Post $R x$

Figure 9) parietal cell sensitivity compared with healthy volunteers (Figure 8). In addition, the $\mathrm{ED}_{50}$ and $\mathrm{K}_{\mathrm{m}}$ remained unchanged in $\mathrm{H}$ pylori-positive patients following eradication or in healthy volunteers following sucralfate or ranitidine (Figures 8, 9).

\section{DISCUSSION}

In the present study, we investigated the effect of $H$ pylori infection and cure on the gastric acid secretory responses and parietal cell sensitivity in patients with DU disease, and examined the influence of different ulcer treatments on such changes, comparing the study population with healthy volunteers. In addition, we determined the serological and histological responses to $H$ pylori eradication.

One limitation of the present study was the high dropout rate at six months and one year after $H$ pylori eradication due to the difficult nature of the protocol and the good symptomatic response to treatment. There was a $40 \%$ patient dropout six months after eradication and a further $12 \%$ dropout one year after eradication. However, all attempts were made to maximize follow-up at six months and one year.

All DU patients demonstrated a positive $H$ pylori-specific antibody titre and evidence of chronic active gastritis with H pylori infection. They showed a 2.7-fold greater BAO than healthy volunteers. Eradication of $H$ pylori was accompanied by a $29 \%$ reduction in BAO one month after treatment. In contrast, El-Omar et al (13) demonstrated a 50\% reduction in BAO. By six months after treatment, a further $10 \%$ decrease in $\mathrm{BAO}$ was evident, and by one year after treatment, $\mathrm{BAO}$ had returned to healthy volunteer levels, in keeping with the findings of Moss et al (30) and El-Omar et al (13). Similarly, Harris et al (31) demonstrated a decrease in BAO in DU patients after $\mathrm{H}$ pylori eradication; however, in that study, BAO levels returned to healthy volunteer levels at six months. Unlike the above studies, the decrease in BAO in our study failed to reach significance. A simple explanation for this is the high degree of variability that was evident be- tween individual patient results confounded by small patient numbers. Similarly, Louw et al (32) demonstrated in a study of nine $H$ pylori-positive DU patients that, after eradication, there was a tendency for basal and low dose pentagastrinstimulated acid secretion to fall over 12 months following eradication; however, only a reduction in high dose pentagastrin-stimulated acid secretion achieved significance at 12 months. Furthermore, if the BAO values determined from various studies are examined, there is a high degree of variability in the pretreatment $\mathrm{BAO}$ (4.1 to 10.7; mean 7.4), suggesting that additional patient/host factors such as cytokine gene polymorphism with cytokine profiles $(33,34)$, blood group antigens, human lymphocyte antigen type, age of infection and environmental exposure (35) are likely important. In addition, the use of different therapeutic regimens may be important. However, despite these potential differences, the BAO was not significantly different among the El-Omar et al (13) study, the Harris et al (31) study and the present study at six months (4.5 and 3 compared with $4.9)$, or between the El-Omar study and the present study at one year (2.5 compared with 2.9).

Previous studies have indicated that the hypergastrinemia associated with $H$ pylori infection resolves one month after eradication $(12,13)$. This suggests that resolution of additional components of the $\mathrm{H}$ pylori-associated inflammatory response is required for the gradual return of $\mathrm{BAO}$ to control levels, including morphological changes in parietal cell mass and acid-secretory responses.

In keeping with the results of Isenberg et al (14), the $H$ pylori-positive DU patients demonstrated significantly higher acid secretory responses to each dose of pentagastrin. Moreover, the PAO was increased 1.35-fold compared with healthy volunteer levels, indicating an increase in parietal cell mass in H pylori-positive patients with DU disease. Cure of $\mathrm{H}$ pylori infection resulted in complete resolution of the increased acid secretory response and $\mathrm{PAO}$, but with values only returning to healthy volunteer levels by one year after treatment. This gradual decline in the acid secretory response paralleled the decrease observed in BAO.

Previous studies in DU patients have demonstrated an increased parietal cell mass with an increased capacity to secrete acid (7). Because gastrin is a trophic hormone, the long term hypergastrinemia associated with $\mathrm{H}$ pylori infection might explain the increased parietal cell mass. In patients with hypergastrinemia secondary to gastrinoma, the increased parietal cell mass generally resolves within three to six months after curative surgery (36). Although gastrin levels were not measured in the present study, we postulate that, with $H$ pylori cure and resolution of the hypergastrinemia (13), there is an associated gradual resolution of the trophic changes in parietal cell mass, with resultant restoration of the acid secretory response to healthy volunteer levels. An additional explanation may lie in the impairment of inhibitory control on gastric secretion at a neuroendocrine level, as suggested by EL-Omar et al (13), who showed that H pyloriinfected patients with DU had a marked increase in gastrinreleasing peptide (GRP)-stimulated acid output that ap- 
proximated maximal acid secretory capacity. Although GRP stimulates acid secretion via antral $G$ cell-induced gastrin release, which in turn stimulates parietal cells to secrete acid $(37,38)$, GRP also stimulates the release of a variety of other hormones that inhibit acid secretion both at the level of gastrin release and at the parietal cell through the release of somatostatin (39-45). This suggests that the acid response to GRP is the result of a dynamic interaction between these two pathways. In H pylori-infected individuals, several studies have shown a decrease in stainable D cell concentrations and messenger RNA expression in the gastric mucosa, which suggests, as EL-Omar et al (13) have postulated, that there is an impairment in the GRP-stimulated inhibitory control. Furthermore, the release of soluble mediators associated with the chronic active gastritis likely affects the secretory capacity of parietal cells and contributes to the acid hypersecretion. Thus, with the eradication of $\mathrm{H}$ pylori, the change in cytokine profiles associated with the gradual resolution of the gastritis are likely important contributing factors.

From a clinical perspective Hamlet and Olbe (46) have demonstrated that the increased acid secretion associated with $H$ pylori results in an increased duodenal acid load. This results in duodenal mucosa injury, the development of gastric metaplasia in the duodenal bulb (47) and subsequent $H$ pylori colonization of the duodenum. Thus, in addition to gastric acid, $\mathrm{H}$ pylori with associated cytotoxins can induce mucosal damage and lead to the development of DU. One may conclude that, by decreasing gastric acid secretory capacity with eradication of $H$ pylori from the gastric antrum and duodenal metaplastic epithelium, the duodenitis will diminish and the duodenal mucosa rendered less susceptible to acid attack. Moreover, gastrin levels (AUC gastrin) also fall, and the trophic stimulus to the secretory mass falls with these gastrin levels (AUC gastrin).

Studies comparing parietal cell sensitivity with gastrin levels in patients with DU and healthy volunteers have produced conflicting results. In the present study, despite the observation that $H$ pylori-infected DU patients secrete more acid than normal healthy volunteers both under basal conditions and in response to graded doses of pentagastrin, no differences were noted in either the apparent or intrinsic parietal cell sensitivity between the two groups or between $\mathrm{H}$ pylori-positive patients before and after treatment. Although these results are in keeping with several studies $(29,40,48-50)$, other studies have suggested an increase in parietal cell sensitivity $(14,15)$. In calculating parietal cell sensitivity from the dose-response curve, it is controversial whether to plot BAO against the zero dose of pentagastrin or to subtract the basal output from the acid output at each pentagastrin dose. This consideration is important when comparing BAO between $H$ pylori-infected DU patients and healthy volunteers where the values are different. To allow for this potential problem, parietal cell sensitivity was calculated using the method described by Hirschowitz (29) in which apparent sensitivity $\left(D_{50}\right)$ is the dose of pentagastrin required to raise the output from basal to $50 \%$ of the estimated maximum and $\mathrm{K}_{\mathrm{m}}$ is the dose of pentagastrin required to raise the output to $50 \%$ of maximum if basal output was zero.

Sucralfate plus triple therapy was associated with a $43 \%$ reduction in $\mathrm{BAO}$ in $\mathrm{H}$ pylori-infected DU patients, whereas ranitidine triple therapy was associated with only a $7 \%$ reduction in BAO. This observation, in conjunction with the findings by Banerjee et al (23), who demonstrated that sucralfate treatment in $\mathrm{H}$ pylori-positive DU patients led to a $50 \%$ decrease in $\mathrm{BAO}$, suggests that sucralfate treatment is associated with a reduction in basal acid secretion. Banerjee et al (23) observed a decrease in the density of H pylori colonization, but not in the severity of the gastritis, suggesting that sucralfate either decreased acid secretion through the suppression of $H$ pylori infection or that sucralfate decreased the density of $H$ pylori infection via a direct action. In the present study, we observed an $H$ pylori eradication rate of $58 \%$ with sucralfate-based triple therapy compared with a $92 \% \mathrm{H}$ pylori eradication rate with ranitidine-based triple therapy. This observation suggests that, although sucralfate may have a suppressant effect on the $H$ pylori infection with a resultant reduction in $\mathrm{BAO}$, ranitidine-based triple therapy was more effective in the eradication of $\mathrm{H}$ pylori. These different eradication rates may reflect an enhanced antibacterial action of metronidazole and tetracycline secondary to ranitidine and bismuth, as suggested by Graham et al (51).

In this study, healthy volunteers demonstrated pretreatment $\mathrm{BAO}$ and stimulated acid output results that were similar to that seen with both $\mathrm{H}$ pylori-negative and $\mathrm{H}$ pyloripositive healthy volunteers, as shown in the El-Omar study (13). Sucralfate had no effect on the acid secretory response in healthy volunteers, whereas ranitidine was associated with an increase in the acid secretory response as evidenced by a 2.2-fold increase in BAO and a 1.1-fold increase in $\mathrm{AUC}_{\mathrm{p}}$. This observation confirms previous reports (24-26), suggesting that $\mathrm{H}_{2}$-receptor upregulation with acid rebound occurs following ranitidine treatment.

In keeping with the results of Cutler and Prasad (52), eradication of the $H$ pylori infection was associated with a mean $43 \%$ decline in the antibody titre one year after cure. In addition, $75 \%$ of the patients examined at one year showed resolution of the gastric inflammation.

In $H$ pylori-positive DU patients who failed to eradicate the infection, there was a higher pretreatment $H$ pylori-specific antibody titre with a 1.7-fold increase compared with that of patients achieving primary cure. Moreover, these patients had a higher basal and pentagastrin-stimulated acid secretory response. Following treatment failure, no changes were noted in either the antibody titre or acid secretory response. However, cure of the infection following a second course of treatment with omeprazole and amoxicillin or erythromycin was characterized by a similar decrease in the antibody concentration and acid secretory response to patients achieving initial cure with bismuth-based triple therapy. Although not addressed in the present study, we postulate that the density of $H$ pylori colonization of the stomach may be important in this regard. Furthermore, ge- 
netic and environmental factors may predispose patients to increased bacterial colonization.

Investigators have postulated that the antibacterial activity of amoxicillin may be improved when the $\mathrm{pH}$ of gastric juice approaches 7 (53-54). Furthermore, increasing doses of proton pump inhibitors increase the cure rate of H pylori infection (54). We, therefore, hypothesize that a subgroup of patients with higher serological titres and higher acid secretory response (as observed in those who failed bismuth-based triple therapy) require a greater degree of acid suppression.

In summary, this study has further confirmed that $\mathrm{H} p y-$ lori-positive DU patients have increased basal and pentagastrin-stimulated acid secretory responses, which resolve by one year after cure, in conjunction with a decline in serological titres and a resolution of gastric inflammation. However,

\section{REFERENCES}

1. Coghlan JG, Gilligan D, Humphries H, et al. Campylobacter pylori and recurrence of duodenal ulcers - A 12 month follow up study. Lancet 1987;ii:1109-11.

2. Marshal BJ, Goodwin CS, Warren JR, et al. Prospective double-blind trial of duodenal ulcer relapse after eradication of Campylobacter pylori. Lancet 1988;ii:1437-41.

3. Rauws EAJ, Tytgat GNJ. Cure of duodenal ulcer associated with eradication of Helicobacter pylori. Lancet 1990;335;1233-5.

4. Hentschel E, Brandstatter G, Dragosics B, et al. Effect of ranitidine and amoxicillin plus metronidazole on the eradication of Helicobacter pylori and the recurrence of duodenal ulcer. N Engl J Med 1993;328:308-12.

5. Bayerdorffer E, Mielke S, Mannes GA, et al. Double-blind trial of omeprazole and amoxicillin to cure Helicobacter pylori infection in patients with duodenal ulcers. Gastroenterology 1995;108:1412-7.

6. Blair AJ, Feldman M, Barnett C, Walsh JH, Richardson CT. Detailed comparison of basal and food-stimulated gastric acid secretion rates and serum gastrin concentrations in duodenal ulcer patients and normal subjects. J Clin Invest 1987;79:582-7.

7. Cox AJJ. Stomach size and its relationship to chronic peptic ulcer. Arch Pathol 1952;54:407-12.

8. Johnson LR, Aures D, Hakansson R. Effect of gastrin on the in vivo incorporation of C14-leucine into protein of the digestive tract. Proc Soc Exp Biol Med 1969;132:996-8.

9. Crean GP, Marshall MW, Runsey RD. Parietal cell hyperplasia induced by the administration of pentagastrin. Gastroenterology 1969;57:147-55

10. Levi S, Beardshall K, Swift I, et al. Antral Helicobacter pylori, hypergastrinemia and duodenal ulcers: effect of eradicating the organism. BMJ 1989;299:1504-5.

11. Graham DY, Opekum A, Lew GM, Evans DJ, Klein PD, Evans DG. Ablation of exaggerated meal-stimulated gastrin release in duodenal ulcer patients after clearance of Helicobacter (Campylobacter) pylori infection. Am J Gastroenterol 1990;85:394-8.

12. McColl KEL, Fullarton GM, Chittajallu R, et al. Plasma gastrin, daytime intragastric $\mathrm{pH}$, and nocturnal acid output before and at 1 and 7 months after eradication of Helicobacter pylori in duodenal ulcer subjects. Scand J Gastroenterol 1991;26:339-46.

13. El-Omar EM, Penman ID, Ardill JES, Chittajallu R, Howie C, McColl KEL. Helicobacter pylori infection and abnormalities of acid secretion in patients with duodenal ulcer disease. Gastroenterology 1995;109:681-91.

14. Isenberg JL, Grossman MI, Maxwell V, Walsh JH. Increased sensitivity to stimulation of acid secretion by pentagastrin in duodenal ulcer. J Clin Invest 1975;55:330-7.

15. Lam SK, Isenberg JI, Grossman MI, Lane WH, Walsh JH. Gastric acid secretion is abnormally sensitive to endogenous gastrin release after peptone test meals in duodenal ulcer patients. J Clin Invest 1980;65:555-62.

16. Halter F, Bangerter U, Hacki WH, et al. Sensitivity of the parietal cell to pentagastrin in health and duodenal ulcer disease. A reappraisal. Scand J Gastroenterol 1982;17:539-44.

17. Gillen D, EL-Omar EM, Wirz AA, Ardill JES, McColl KEL. The acid this study failed to demonstrate that $\mathrm{H}$ pylori-positive DU patients have increased parietal cell sensitivity. In $\mathrm{H}$ pyloripositive DU patients who failed bismuth-based triple therapy, higher serological titres and acid secretory responses were observed, which raises the possibility of greater density of bacterial colonization of the stomach.

Although the mechanisms underlying the increased acid secretory responses in $\mathrm{H}$ pylori-positive patients with DU disease remain unclear, the duration taken for normalization of this response as demonstrated in this study suggests that resolution of parietal cell morphological changes are important.

ACKNOWLEDGEMENT: We thank Chugai Pharmaceuticals for their support and co-operation with this project.

response to gastrin distinguishes duodenal ulcer patients from Helicobacter pylori-infected healthy subjects. Gastroenterology 1998;114:50-7.

18. Moss SF, Legon S, bishop AE, Polak JM, Calam J. Effect of Helicobacter pylori on gastric somatostatin in duodenal ulcer disease. Lancet 1992;340:930-3.

19. Kaneko H, Nakada K, Mitsuma T, et al. Helicobacter pylori infection induces a decrease in immunoreactive-somatostatin concentrations of the human stomach. Dig Dis Sci 1992;37:409-16.

20. Marks IN, Young GO, Tigler-Wybrand NA, Bridger S, Newton KA. Acid-secretory responses and parietal cell sensitivity in patients with duodenal ulcer disease before and after treatment with sucralfate or ranitidine. Am J Med 1989;86(Suppl 6A):145-7.

21. Johnston DA, Marks IN, Young GO, Tigler-Wybrand NA, Bridger S. Duodenal ulcer healing and acid secretory responses to modified sham feeding and pentagastrin stimulation. Aliment Pharmacol Ther 1990;4:403-10.

22. Kummer AF, Johnston DA, Marks IN, Tigler-Wybrand NA, Bridger S, Young GO. Changes in nocturnal acid secretion on duodenal ulcer healing with ranitidine and sucralfate. Gut 1990;31:A599. (Abst)

23. Banerjee S, El-Omar E, Mowat A, et al. Sulcrate suppresses Helicobacter pylori infection and reduces gastric acid secretion by $50 \%$ in patients with duodenal ulcer. Gastroenterology 1996;110:717-24.

24. Jones DB, Howden CW, Burgdet DW, Siletti C, Hunt RH. Alterations of $\mathrm{H}_{2}$-receptor sensitivity in duodenal ulcer patients after treatment with an $\mathrm{H}_{2}$-receptor antagonist. Gut 1988;29:890-3.

25. Aadland E, Berstad A. Parietal and chief cell sensitivity to histamine and pentagastrin stimulation before and after cimetidine treatment in healthy subjects. Scand J Gastroenterol 1979;14:933-8.

26. Fullarton GM, McLaughlan G, MacDonald A, Crean GP, McColl KEL. Rebound nocturnal hypersecretion after four weeks treatment with an $\mathrm{H}_{2}$-receptor antagonist. Gut 1989;30:449-54.

27. El-Omar E, Banerjee MD, Wirz A, Penman I, Ardill JES, McColl KEL. Marked rebound acid hypersecretion after treatment with ranitidine. Am J Gastroenterol 1996;91:355-9.

28. Hassan HA, Hobsley H. Positioning of subject and of nasogastric tube during a gastric secretion study. BMJ 1970;i:458-60.

29. Hirschowitz BI. Apparent and intrinsic sensitivity to pentagastrin of acid and pepsin secretion in peptic ulcer. Gastroenterology 1984;86;843-51.

30. Moss SF, Ayesu K, Calam J. Gastrin and gastric acid output 1 year after eradication of Helicobacter pylori in duodenal ulcer patients. Regul Pept 1991;35:A251. (Abst)

31. Harris AW, Gummett PA, Misiewicz JJ, Baron JH. Eradication of Helicobacter pylori in patients with duodenal ulcer lowers basal and peak acid outputs to gastrin releasing peptide and pentagastrin. Gut 1996;38:663-7.

32. Louw JA, Young GO, Lucke W, Bridger S, Winter TA, Marks IN. Basal and pentagastrin stimulated acid secretion in duodenal ulcer 
subjects before and after Helicobacter pylori eradication: a 12-month follow-up study. Ital J Gastroenterol Hepatol 1998;30:363-7.

33. Blaser MJ. Linking Helicobacter pylori to gastric cancer. Nat Med 2000;6:376-7.

34. El-Omar EM, Carrington M, Chow WH, et al. Interleukin-1 polymorphisms associated with increased risk of gastric cancer. Nature 2000;404:398-402.

35. Covacci A, Telford JL, Giudice GD, Parsonnet J, Rappouli R. Helicobacter pylori virulence and genetic geography. Science 1999;284:1328-33.

36. Pisegna JR, Norton JA, Slimak GG, et al. Effect of curative gastrinoma resection on gastric secretory function and antisecretory drug requirement in the Zollinger-Ellison syndrome. Gastroenterology 1992;102:767-78.

37. Walsh JH, Maxwell V, Ferrari J, Varner AA. Bombesin stimulates human gastric function by gastrin-dependent and independent mechanisms. Peptides 1981;2(Suppl 2):193-8.

38. Lundell L, Lindstedt G, Olbe L. Origin of gastrin liberated by gastrin releasing peptide in man. Gut 1982;28:1128-33.

39. Glad H, Svendsen P, Ainsworth MA, Olsen O, Rehfeld JF, Schaffalitzky De Muckadell OB. The effect of gastrin releasing peptide on porcine pancreatobiliary bicarbonate secretion is mediated by secretin. Scand J Gastroenterol 1994;29:195-202.

40. Hirschowitz BI, Tim LO, Helman CA, Molina E. Bombesin and G-17 dose responses in duodenal ulcer and controls. Dig Dis Sci 1985;30:1092-103.

41. Greenberg GR, Chan B, MacDonald TJ, Alleyne J. The role of vagal integrity in gastrin releasing peptide stimulated gastroenteropancreatic hormone release and gastric acid secretion. Regul Pept 1985;10:179-87.

42. Villar HV, Fender HB, Rayford PL, Bloom SR, Ramus NI, Thompson JC. Suppression of gastrin release and gastric secretion by gastric inhibitory peptide (GIP) and vasoactive intestinal polypeptide (VIP). Ann Surg 1976;184:97-102.

43. Wolfe MM, Reel GM, McGuigan JE,. Inhibition of gastrin release by secretin is mediated by somatostatin in cultured rat antral mucosa. J Clin Invest 1983;72:1586-93.

44. Wolfe MM, Reel GM. Inhibition of gastrin release by gastric inhibitory peptide mediated by somatostatin. Am J Physiol 1986;250:G331-5

45. Chiba T, Taminato T, Kadowaki S, et al. Effect of glucagon, secretin, and vasoactive intestinal polypeptide on gastric somatostatin and gastrin release from isolated perfused stomach. Gastroenterology 1980;79:67-74.

46. Hamlet A, Olbe L. The influence of Helicobacter pylori on postprandial duodenal acid load and doudenal bulb $\mathrm{pH}$ in humans. Gastroenterology 1996;111:391-400.

47. Khulusi S, Badve S, Patel P, et al. Pathogenesis of gastric metaplasia of the human duodenum: role of Helicobacter pylori, gastric acid, and ulceration. Gastroenterology 1996;110:452-8.

48. Petersen H, Myren J. Pentagastrin-dose response in peptic ulcer disease. Scand J Gastroenterol 1975;10:705-14.

49. Chittajallu RS, Howie CA, McColl KEL. Effect of Helicobacter pylori on parietal cell sensitivity to pentagastrin in duodenal ulcer subjects. Scand J Gastroenterol 1992;27:857-62.

50. Moss SF, Calam J. Acid secretion and sensitivity to gastrin in patients with duodenal ulcer: effect of eradication of Helicobacter pylori. Gut 1993;34:888-92.

51. Graham DY, Lew GM, Evans DJ Jr, Klein PD. Effect of triple therapy (antibiotics plus bismuth) on duodenal ulcer healing. A randomized controlled trial. Ann Intern Med 1991;115:266-9.

52. Cutler AF, Prasad VM. Long-term follow-up of Helicobacter pylori serology after successful eradication. Am J Gastroenterol 1996;91:85-7.

53. Bayerdorffer E, Mannes GA, Sommer A, et al. High dose omeprazole treatment combined with amoxicillin eradicates Helicobacter pylori. Eur J Gastroenterol Hepatol 1992;4:697-702.

54. Mannes GA, Bayerdorffer E, Hele C, Rusckdeschel G, Stolte M. An increasing dose of omeprazole combined with amoxicillin increases the eradication rate of Helicobacter pylori. Gastroenterology 1993;104:A140. (Abst) 


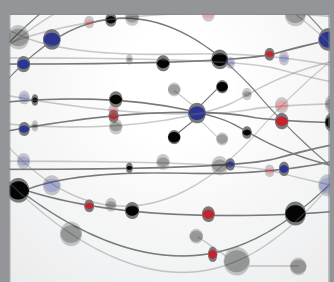

The Scientific World Journal
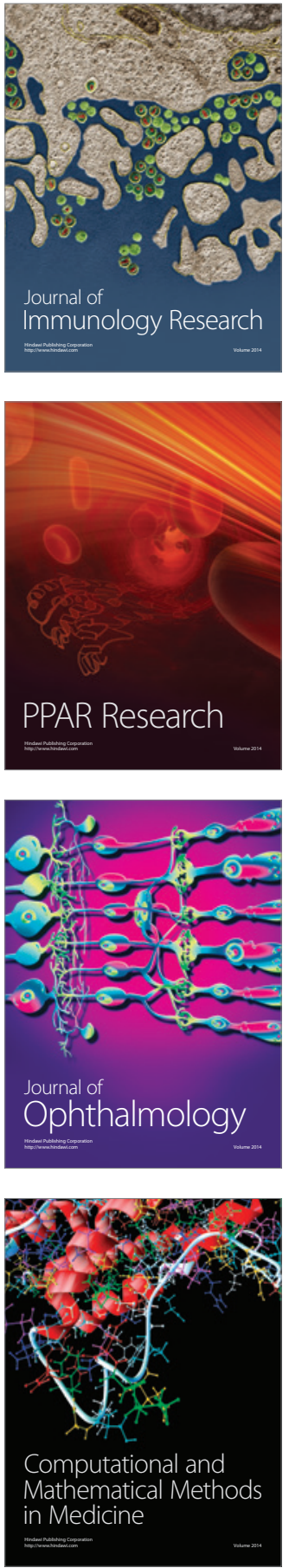

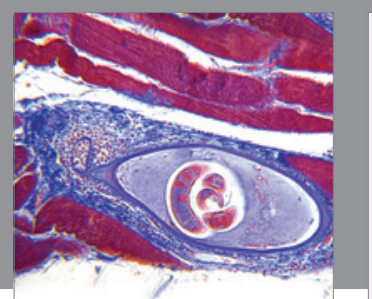

Gastroenterology Research and Practice

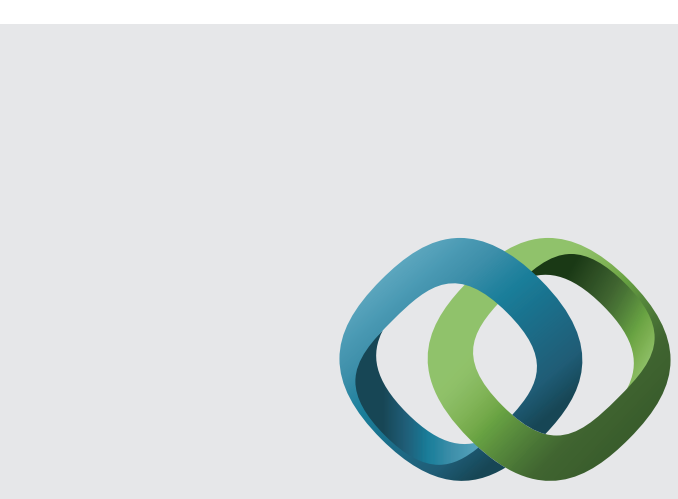

\section{Hindawi}

Submit your manuscripts at

http://www.hindawi.com
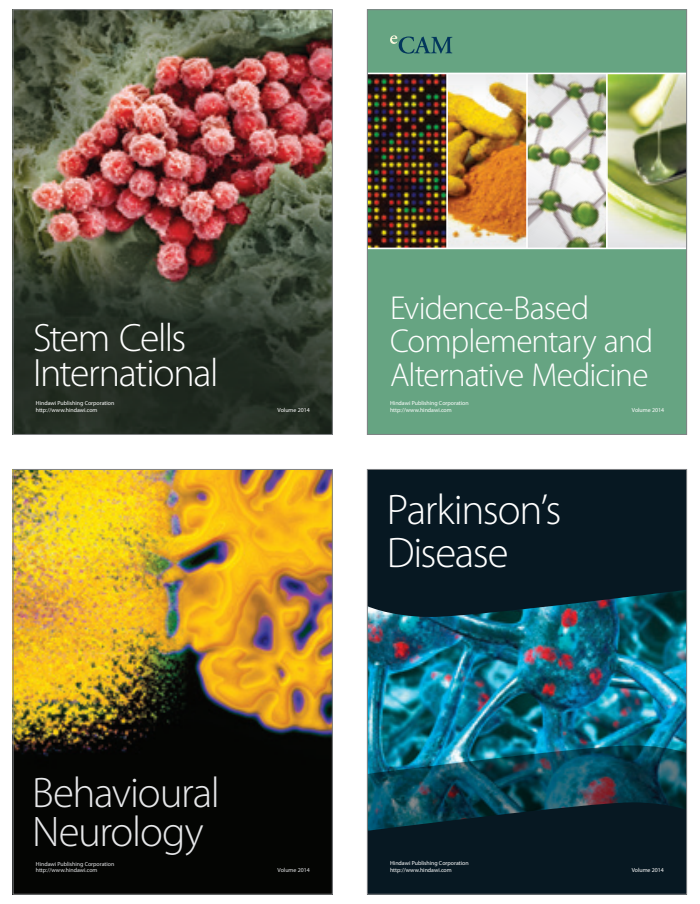
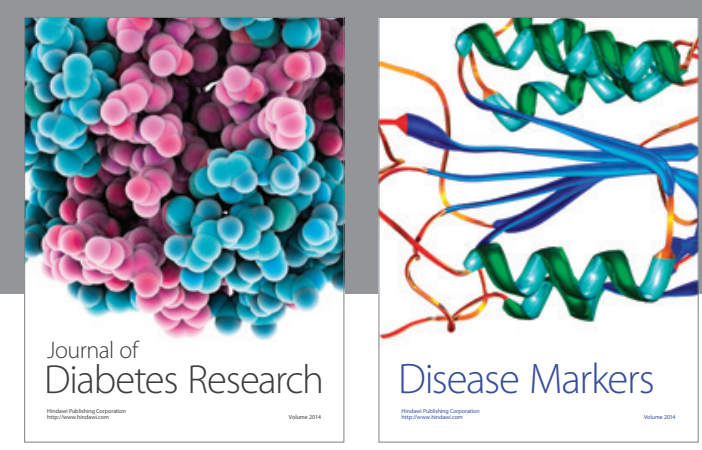

Disease Markers
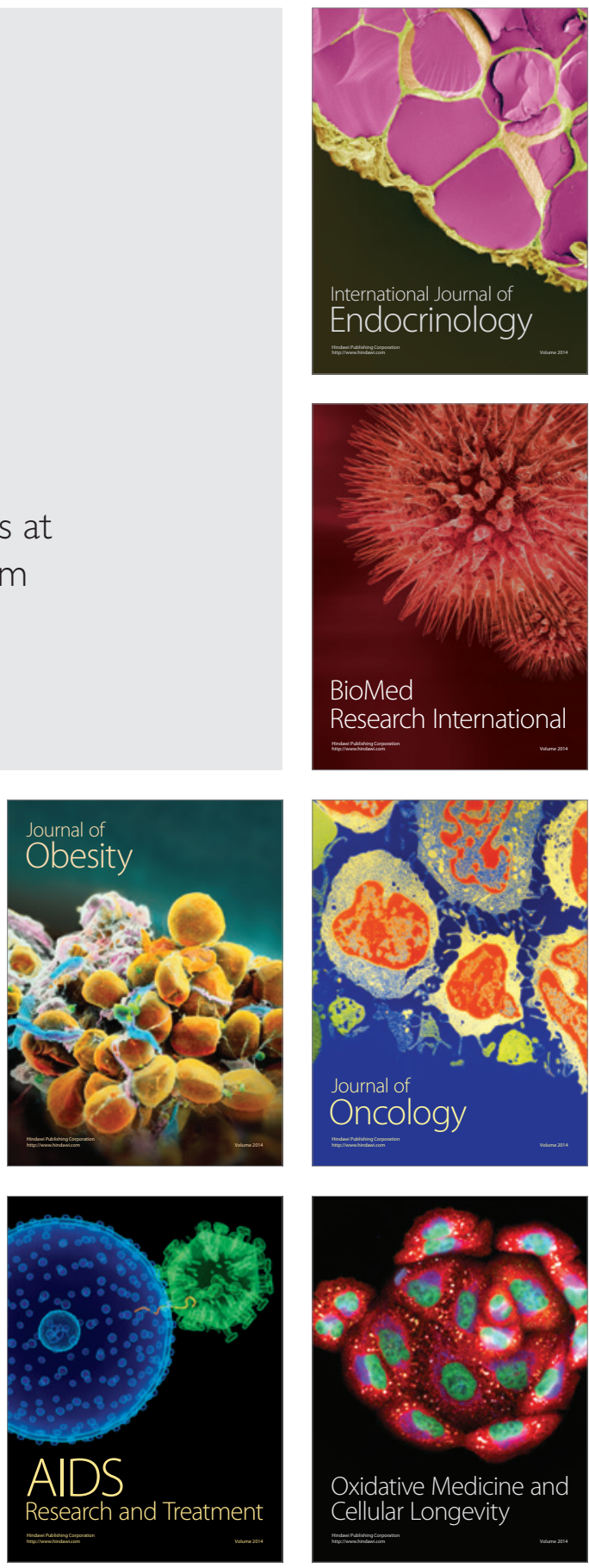